\title{
Characterization of Bentonite by XRD and SEM-EDS and Use to Increase PH and Color Removal, Fe and Organic Substances in Peat Water
}

\author{
Muhammad Naswir, Susila Arita, Marsi, and Salni
}

\begin{abstract}
XRD analysis showed that Bentonite area of Jambi region composed of the mineral kaolinite, monmorrilonit, quartz and cristobalit. Minerals that are most monmorillonit the average content was $51.96 \%$, with an average density of $2193 \mathrm{~g}-1 \mathrm{~cm}-1$. The results of the analysis by Scanning Electron Microskopy (SEM) and Energy Disvertive Spektroskopy (EDS), showed that the shape of smooth surfaces and coated bentonite, the biggest constituent composition is $\mathrm{SiO} 2$ and $\mathrm{Al} 2 \mathrm{O} 3$ with an average of $50.01 \%$ and $30.65 \%$ by weight. The ability of bentonite to improve $\mathrm{pH}$, color, $\mathrm{Fe}$ and organic matter peat water is relatively varied. The addition of bentonite did not significantly affect the $\mathrm{pH}$ of peat water, but good enough in reducing the color content $65.60 \%$, organic matter $59.1 \%$, and $35.89 \%$ Fe contained in the peat water.
\end{abstract}

Index Terms-Bentonite, $\mathrm{X}$ ray diffraction, SEM-EDS, peat water

\section{INTRODUCTION}

The crucial problem in the Lowland is water scarcity, although in this area the peat abundant amount of water, but it is have not been able to be used effectively. Indonesia is one country in the world that has the largest peat swamp. Peat swamp in Indonesia is approximately 16-27 million hectares [1]. Of the about 7.2 million hectares area or $35 \%$ are located on the island of Sumatra, include Jambi region [2]. People whose living in peat land often have difficulty getting clean water, even in this area there is an abundance of peat water, but it needed a technology to process it.

The peat water is brownish red, acidic, having a high content of organic matter, do not meet water quality requirements [3]-[5]. The acid has acidic character due to carboxylic and phenolic groups. Peat water have to be characterized as being gererally be yellow-brown color, the acid are the main constituens of the dissolved organic carbon pool in surface waters, water grounds, commonly imparting a yellowish-brown to the water system. Water quality peat differ from one region to another, Depending on the condition and age of peat soil, such as water quality peat West Kalimantan has a turbidity of 60 NTU, color, 804 Pt.Co, $\mathrm{pH} 4.8$, organic matter $246.8 \mathrm{ppm}$, while the water content of the peat area of Edinburgh has 952 Pt.Co color, 3:34 to 5:20 $\mathrm{pH}$, organic matter $332 \mathrm{ppm}$ [5], [6]. Peat water have dark brown surfaced or black surfaced with a TDS content of 60 NTU, 124-850 PtCo color, organic matter content of

Manuscript received October 9, 2012; revised December 18, 2012.

The authors are with nvironmetal Sciences Programe, Sriwijaya University, Indonesia (e-mail: m.naswir@yahoo.com).
138-1560 mg / $1 \mathrm{KMnO} 4$, and acidic $\mathrm{pH} 3.7$ to 5.3 [7]. While on the Siak River in Pekan Baru is contained pH 5.2, ion $\mathrm{Fe}^{+3}$ ion $1.623 \mathrm{ppm}$ and $0.67 \mathrm{ppm} \mathrm{Cu}^{+2}$ [4]. While the water in the river Siantan Kalimantan peat have the intensity of the color ranges from $656 \mathrm{TCU}$ [8].

Water treatment technologies which developed lately is Reverse osmosis technology which is used to reduce levels of salt in the water [9]. This technology can produce more clean water and can be combined with other treatment systems. Reverses osmoses is a technology that uses a semi-permeable membrane that allows the membrane to separate the components of microorganisms present in water and suitable for the environment [10]. Peat water can be treated with the addition of the use of Poly Aluminium Clorida (PAC) which can reduce color intensity water peat from 624 to $15 \mathrm{TCU}$ [11]. One Stage coagulation Method [12], the combination Uplflow Anaerobic Filter method (UAF) and the Slow Sand Filter (SSF) can reduce the color concentration of $804 \mathrm{PtCo}$ peat water to $11 \mathrm{PtCo}$ [13], using Aeration pump and filter from sand [28] and [4], They have successfully use bentonite to reduce parameter ion $\mathrm{Fe}^{+3}$ and $\mathrm{Cu}^{+2}$ ions on peat water Siak river Riau. Removal of Nitrogen in $\mathrm{NH}_{4}{ }^{+}$from aqueos solution using natural clay and zeolit and one eksperiment has sucsessfull to use titanium sulfat for flucolation to water treatment and most effective in the range $\mathrm{pH} 4-6$ [13]

In the research, for water treatment to using of bentonie material. Jambi has a quite a lot of Bentonite deposite but have not been put to be used effectively [15]. From the survey of PT Mapalus Manggala Engineering is known that deposit of bentonite is found in the Bangko 4400 ha, Bungo and Tebo 520 ha, Batanghari 1350 ha and 200 ha Sarolangun [16]. Bentonite has a good ability in absorbing, so it can be used to absorb organic matter, and Fe which contained in the peat water.

\section{MAterials AND Methods}

\section{A. Preparation of Samples of Bentonite}

Bentonite which is used in the capture of five locations in the area and local, Sarolangun Merangin Bangko, Tanjung Rambai, Pauh, Biku Tanjung Rengas Island and Pandan Island. Bentonite samples taken each region by $10 \mathrm{~kg}$ in the form chunks land and fractions, the samples dried by the hot sun, oven at a temperature of $110^{\circ} \mathrm{C}$ for 4 hours and up to size 150 mess mashed up into powder

\section{B. Characterization of Bentonite with XRD}

Characterization of the composition of the minerals 
contained in bentonite samples conducted at the Laboratory of the Faculty of Mining ITB Bandung, using X-ray Diffraction instruments, Analytical brand Philips PC-APD, Diffraction Diffractometer software type: PW1710 BASED, Tube anode: $\mathrm{Cu}$ Generator tension [kV]: 40, generator current [mA]: 30, alpha1 Wavelength: 1.54060, Alpha2 Wavelength: 1.54439, Intensity ratio (alpha2/alpha1): 0500, Divergence slit: 10, Receiving slit: 0.45 and Type of scan: CONTINUOUS

\section{Analysis by SEM and EDS}

Scanning Electron Microscopy SEM-EDS brand Instrument JEOL JSM 6510L A is used to observe the surface of cells or other microscopic structures, and observations and is able to display three-dimensional objects. Scanning Electron Microscopy (SEM) is an electron that describes the sample by scanning a beam of electrons in a raster scan pattern. The electrons interact with the atoms that make up the sample producing signals that contain information about the sample surface topography, composition and properties - properties such as electrical conductivity. Scanning Electron Microscopy (SEM) aims to look at the structure and shape of the surface of bentonite, while to know the composition of the building blocks of bentonite used Enegri Dispertive Spektroskopy (EDS). Prior to the SEM-EDS measurements performed by drying the mixture of bentonite using the oven at $110^{\circ} \mathrm{C}$ for 4 hours. bentonite then smoothed with size 150 mess.

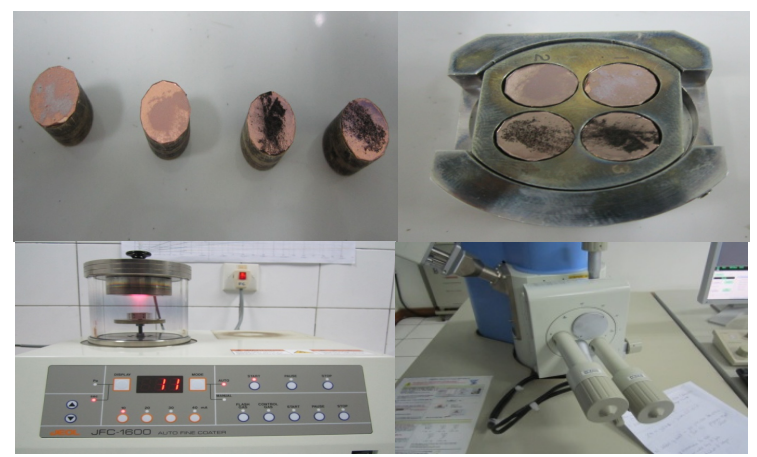

Fig. 1. Foto proses coating sampel JEO. L JFC-1600 Auto Finen Coater and SEM-EDS JEOL JESM 6510 LA

\section{Effect of the Addition of Bentonite on Some}

Chemicals compound which used is peat water, distilled water, concentrated $\mathrm{HCl}, \mathrm{KMnO}_{4}$, buffer $\mathrm{pH} 4$, $\mathrm{pH} 7$ buffer, buffer $\mathrm{pH} 10, \mathrm{~K}_{2} \mathrm{PtCl}_{6}, \mathrm{CoCl}_{2} \cdot 6 \mathrm{H}_{2} \mathrm{O}$, hydroxylamine, sodium acetate, fenantrolin, $\mathrm{FeCl}_{3} \cdot 6 \mathrm{H}_{2} \mathrm{O}, \mathrm{H}_{2} \mathrm{SO} 4_{\text {pa }}$. HANNA Instruments $\mathrm{pH}$ Meter brands (ISO 9001 sertified company), UVvis, turdimetri, TDS meter. Peat water samples taken in the area of Jambi Muaro Tangkit as 200 liters. The addition of bentonite performed a total of 1, 2,3,4 and 5 grams in 500 $\mathrm{ml}$ of water into the peat that had been prepared in a beaker, replicates performed three times. The number of all treatments is 45 samples. peat water that has been added bentonite in the mix for 1-2 minutes, and let stand for 30 minutes, followed by filtration and the filtrate was measured by $\mathrm{pH}$, color, $\mathrm{Fe}$ and organic matter.

\section{RESUlTS AND DISCUSSION}

\section{A. XRD in Various Types of Bentonite}

The results of the characterization of bentonite by X Ray Diffraction showed that bentonite Jambi area generally composed of 4 types of mineral; kaolinite, monmorrilonit, quartz and cristobalit. The most Mineral monmorillonit found in bentonite Biku Tanjung 72.3\%, 69.8\% and Rengas Island Pauh as much as $65.9 \%$, with an average density of $2193 \mathrm{~g}-1 \mathrm{~cm}-1$. Weight ratio percentage of each mineral contained is shown in Table I.

TABLE I: THE RESUlTS OF ANALYSIS BY XRD BE SOME KIND OF

\begin{tabular}{|l|l|l|l|l|l|l|}
\hline \multirow{2}{*}{$\begin{array}{l}\text { Bent } \\
\text { onit }\end{array}$} & Kaolin & $\begin{array}{l}\text { Quart } \\
\mathrm{z}\end{array}$ & $\begin{array}{l}\text { Montm } \\
\text { orilloni } \\
\mathrm{t}\end{array}$ & $\begin{array}{l}\text { Crist } \\
\text { obali } \\
\mathrm{te}\end{array}$ & $\begin{array}{l}\text { Density } \\
(\mathrm{g} 1 \mathrm{~cm}-3)\end{array}$ & $\begin{array}{l}\mu / \mathrm{dx} \text { mix } \\
(\mathrm{cm} 2 \mathrm{~g}-1)\end{array}$ \\
\hline $\begin{array}{l}\text { B.B } \\
\mathrm{T}\end{array}$ & 10.3 & 4.0 & 65.9 & 19.7 & 2,210 & 25.0 \\
\hline B.P & 39.0 & 0.4 & 56.2 & - & 2,087 & 22.4 \\
\hline $\begin{array}{l}\text { B.T. } \\
\text { R }\end{array}$ & 21.6 & 18.2 & 59.8 & 08.1 & 2,114 & 24.1 \\
\hline $\begin{array}{l}\text { B.P. } \\
\text { P }\end{array}$ & 0.86 & 21.4 & 29.6 & 05.5 & 2,380 & 26.2 \\
\hline $\begin{array}{l}\text { B.P. } \\
\text { R }\end{array}$ & 07.6 & 0.20 & 75.3 & 15.4 & 2,174 & 23.4 \\
\hline
\end{tabular}

X-ray diffraction spectrum of several types of bentonite area of Jambi

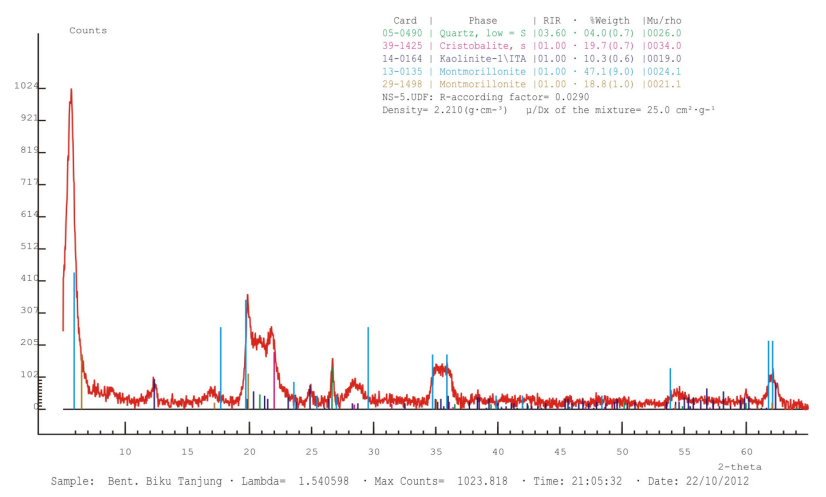

Fig. 2. Spektrum XRD of bentonit biku tanjung

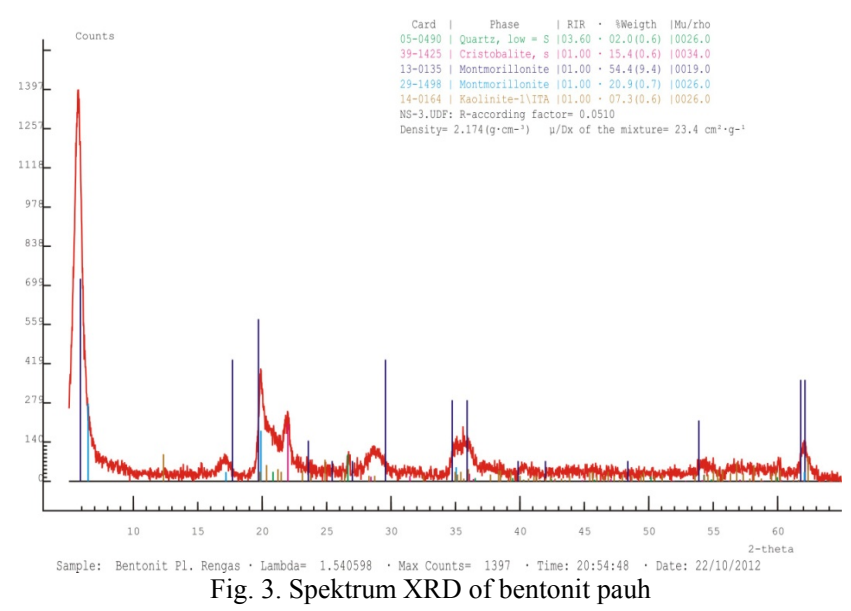

The above XRD spectra showed that bentonite Jambi area is a mixture of several minerals, such as; kaolinite, quartz, montmorillonite, and cristobalite. The most mineral montmorillonite bentonite is in Rengas Island is $69.8 \%$ and 
65.9\% Biku Tanjung. Bentonite Jambi region possessed an average density of $2193 \mathrm{~g}^{-1} \mathrm{~cm}^{-3}$. The composition of some bentonite can be summarized in Table 1. Among the most contents is montmorillonite. Montmorrilonit is a mineral that contains compounds $\mathrm{Al}_{2} \mathrm{O}_{3} 4 \mathrm{Si} . \mathrm{H}_{2} \mathrm{O}$ [17], other minerals contained in the bentonite is $\mathrm{Mg}$ and $\mathrm{Ca}$ occasionally. Bentonite lattice structures composed of a single plate located between two $\mathrm{Al}_{2} \mathrm{O}_{3} \mathrm{SiO}_{2}$ plates. Since the structure is montmorillonite can expand and contract, and have the power of water and cation adsorption higher, Besides that bentonite can also be used as catalyst supports [18]. Bentonite also to using for absorption Metlyn blue and $\mathrm{Cu}^{+2}$ [19] and absorption of $\mathrm{Cu}^{+2}$ [2].

Kaolinite is clay that is rarely found in a pure state, it is a major part of the kaolin clay and it is a very good type, consisting of aluminosilicate minerals $\left(\mathrm{Al}_{2} \mathrm{O}_{3} \mathrm{SiO}_{2} \mathrm{H}_{2} \mathrm{O}\right)$. Pure kaolinite color is generally white, gray white, yellowish or brownish. [20]. Quartz (Quartz) is one of the minerals that are commonly found in the earth's continental crust. This mineral has a hexagonal crystal structure made of trigonal crystallized silica (silicon dioxide, $\mathrm{SiO}_{2}$ ), with 7 Mohs hardness scale and density of $2.65 \mathrm{~g} / \mathrm{cm}^{-3}$. The Quartz is a mineral consisting of crystalline silica (silicon dioxide $\left(\mathrm{SiO}_{2}\right)$ and it crystallizes in the trigonal system. Quartz has a hardness 7 on the Mohs scale. Well-formed quartz crystals have a prismatic six-field. Quartz generally uncolored and clear, which is known as the crystal shape rocks, these minerals have become prezoelektrik properties that can be used as oscillators for clock, radio, and radar. Quartz is used in optical equipment and in glass, glaciers and abrasive. Mineral Cristobalite is a high-temperature Polymorph gravel soil, the compound is the main constituent is $\mathrm{SiO}_{2}$ [21].

Generally found in areas with low rainfall. Besides Bantonit (montmorillonite) mineral sample types 2:1 vermiculite and mica [22]. Kaolinite is a 1:1 clay a silica tetrahedral is lingked with the octahedral alumina sheet by a sahred oxygen [23]

TABLE II: ELEMENT COMPOSER OF BENTONITE

\begin{tabular}{cccccc}
\hline \multirow{2}{*}{ Element } & \multicolumn{5}{c}{ Sample of Bentonite } \\
\cline { 2 - 6 } & B.BT & B.P & B.T.R & B.P.P & B.P.R \\
\hline C K & 14.24 & 8.11 & 8.31 & 7.26 & 19.26 \\
O & 41.00 & 43.57 & 44.31 & 45.55 & 38.81 \\
Na K & - & 0.04 & 0.08 & 0.02 & 0.08 \\
Mg K & 0.11 & 0.19 & 0.08 & 0.78 & 0.87 \\
Al K & 17.09 & 16.48 & 20.79 & 10.70 & 9.92 \\
Si K & 20.62 & 23.80 & 21.65 & 29.99 & 24.60 \\
Cl K & 0.75 & 2.22 & 0.75 & 0.97 & 1,56 \\
K K & 0.04 & 0.62 & 0.09 & 0.15 & 0.11 \\
Ti K & 0.40 & 0.42 & 0.05 & 0.12 & 0.10 \\
Ca K & 0.00 & - & 0.05 & 0.07 & 0.01 \\
Fe K & 1.73 & 3.38 & 1.46 & 2.74 & 2.43 \\
Cu K & 3.08 & 1.19 & 2.42 & 1.66 & 2.25 \\
\hline
\end{tabular}

\section{B. SEM-EDS Analysis of Bentonite}

The results of the analysis by Scanning Electron Microskopy (SEM) and Energy Disvertive Spektroskopy (EDS), showed that the shape of bentonite is smoothed surfaces and coated, the biggest constituent composition is
$\mathrm{SiO}_{2}$ and $\mathrm{Al}_{2} \mathrm{O}_{3}$ with an average of $50.01 \%$ and $30.65 \%$ by weight, Carbon and its compounds others as in Table II and III.
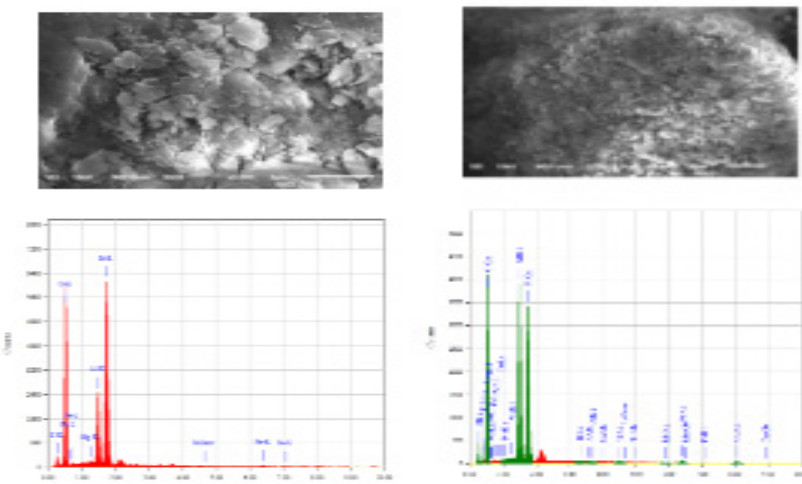

Fig. 4. Spektrum SEM-EDS Bentont.B.Tanjung dan pauh

TABLE III: THE COMPOSITION OF THE BUILDING BLOCKS OF BENTONITE

\begin{tabular}{cccccc}
\hline \multirow{2}{*}{ Compund } & \multicolumn{5}{c}{ Sampel of Bentonite } \\
\cline { 2 - 6 } & B.BT & B.P & B.T.R & B.P.P & B.P.R \\
\hline $\mathrm{SiO}_{2}$ & 44.11 & 50.92 & 46.32 & 64.16 & 52.63 \\
$\mathrm{Al}_{2} \mathrm{O}_{3}$ & 33.61 & 31.09 & 39.26 & 20.22 & 18.75 \\
$\mathrm{TiO}_{2}$ & 0.66 & 0.70 & 0.08 & 0.20 & 0.17 \\
$\mathrm{CaO}$ & 0.01 & - & 0.08 & 0.10 & 0.01 \\
$\mathrm{MgO}$ & 0.19 & 0.31 & 0.06 & 1.30 & 1.45 \\
$\mathrm{~K}_{2} \mathrm{O}$ & 0.04 & 0.75 & 0.11 & 0.18 & 0.13 \\
$\mathrm{Na}_{2} \mathrm{O}$ & - & 0.06 & 0.11 & 0.03 & 0.11 \\
$\mathrm{FeO}$ & 2.22 & 4.35 & 1.88 & 3.53 & 3.13 \\
$\mathrm{CuO}$ & 3.85 & 1.49 & 3.03 & 2.07 & 2.82 \\
$\mathrm{C}$ & 14.24 & 8.11 & 8.31 & 7.26 & 19.26 \\
\hline
\end{tabular}

C. The Influence of Bentonites to Parameter'S of Peat Water

The addition of bentonite in the peat water did not significantly affect the $\mathrm{pH}$ of peat water change, but enough to affect the color reduction, $\mathrm{Fe}$ and organic matter in peat water.

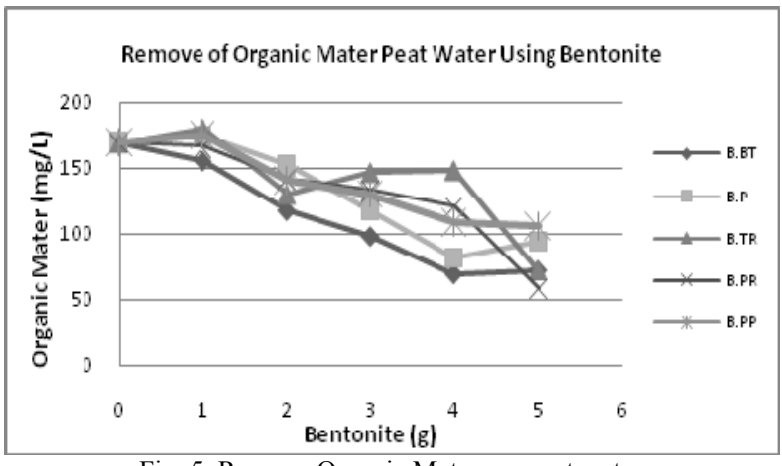

Fig. 5. Remove Organic Mater on peat water

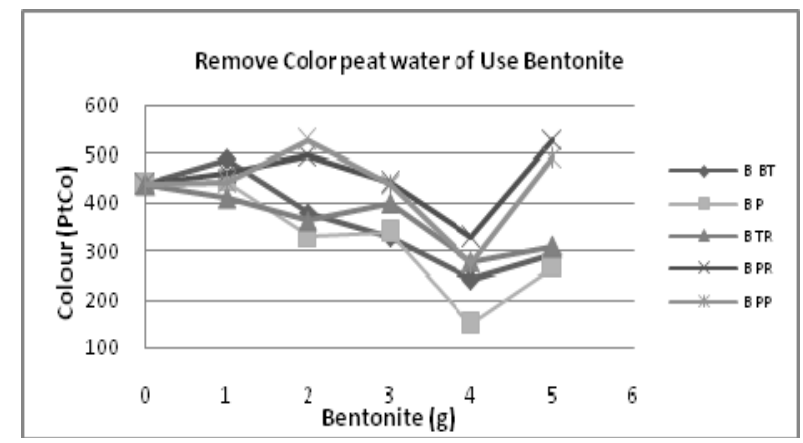

Fig. 6. Remove Color on peat water 


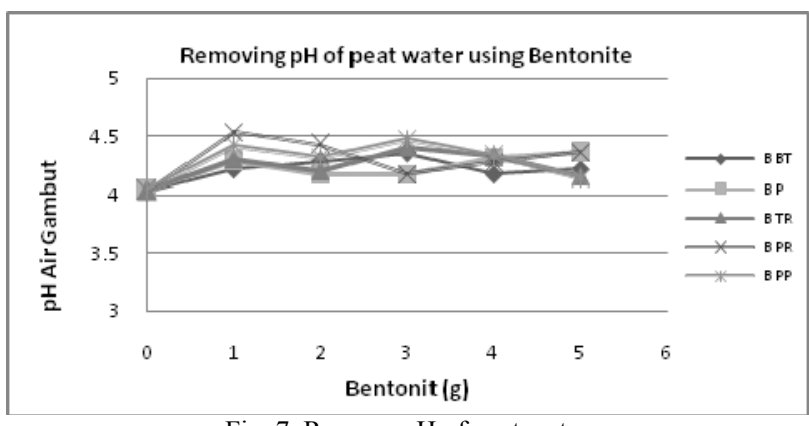

Fig. 7. Remove $\mathrm{pH}$ of peat water

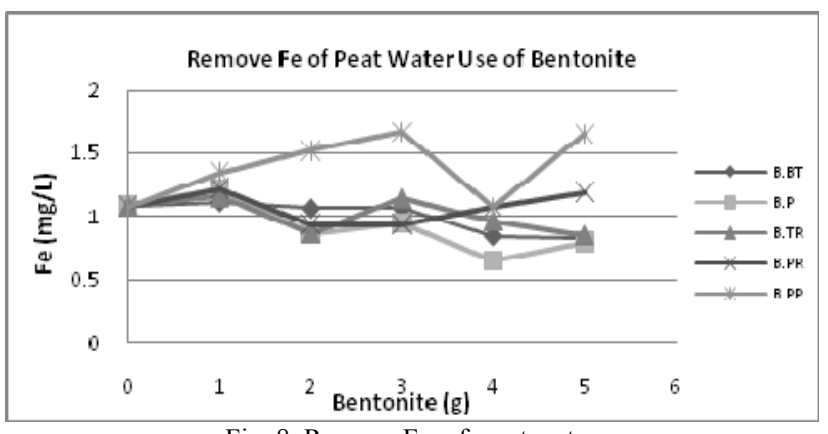

Fig. 8. Remove Fe of peat water

B BT is Bentonite of Biku Tanjung, B P is Bentonite of Pauh, B TR is Bentonite of Tanjung Rambei, BPR is Bentonite of Pulau Rengas and B PP is bentonite of Pulau Pandan

These results indicate that the ability of bentonite to improve the $\mathrm{pH}$, color, $\mathrm{Fe}$ and organic matter peat water is relatively varied. The addition of bentonite did not significantly affect the $\mathrm{pH}$ of peat water, but enough to lower aik color content $(65.60 \%)$, organic matter $(59.1 \%)$, and $35.89 \% \mathrm{Fe}$. The ability to absorb organic bentonite, Fe and peat water color due to the nature of fluid power strong, and expands when mixed with water and can adsorb various substances dissolved in water

Averange $85 \%$ of bentonite consists of montrorillonit, while the other components are : beidellite, saponite, saponite and other minerals. Montrorillonit structure can undergo substitution of other metal-lattice kisis between, for example, substituting metal alumium and poaspor replace silicon in tetra hedral coordinates. And metals, Fe, Mg, Zn, Ni, Li can be replaced the aluminum octahedral layer. Bentonite granules are fine and stable secondary product on the condition of the earth's surface, which formed in nature through four processes: weathering, because the solution of hydrothermal alteration processes, the transformation of the turf rocks glass and chemically deposition process [23], [24].

From this research it is known that Bentonite Jambi region has an average content of $51,63 \% \mathrm{SiO}_{2}$ and $28.58 \%$ of $\mathrm{Al}_{2} \mathrm{O}_{3}$, different from other regions such as bentonite from Songkhla province $\mathrm{SiO}_{2}$ content of $63.97 \%$ and $15.66 \% \mathrm{Al}_{2} \mathrm{O}_{3}$ [22] and chemical formula monmorillonit toritis is $(\mathrm{OH}) 4 \mathrm{Si}_{8} \mathrm{Al}_{4} \mathrm{O}_{2} \cdot \mathrm{nH}_{2} \mathrm{O}\left(\mathrm{SiO}_{2} 66 \%, \mathrm{Al}_{2} \mathrm{O}_{3} 28.3 \%\right.$ and $5 \% \mathrm{H}_{2} \mathrm{O}$ [23], [25]. Bentonite has a layered structure with the ability to inflate (swelling) and have cations that can be exchanged. Bentonite is a mineral silica and expressed as hydrated aluminosilicate According [23], [19].

According to [5], that the $\mathrm{pH}$ in forested areas is higher than the $\mathrm{pH}$ of the water in the peat is formed as canals, because pristine forests land still contains many cations cations such as $\mathrm{Ca}, \mathrm{Mg}$, and $\mathrm{K}$ which can increase alkalinity of soil and water properties. Increased acidity of peat water alongside the elevated levels of iron. Acidity and increased $\mathrm{Fe}$ ions on peat water are the result of compound pyrite $\left(\mathrm{FeS}_{2}\right)$ is oxidized in an aerobic atmosphere.

Organic content in the water is dominated by peat humic compounds which possess aromatic bond complex with functional groups such as- $\mathrm{COOH}$, OH-phenolic and alcoholic $\mathrm{OH}$ and is nonbiodegradable and fulvic acid . This trait also causes most of the water Organic peat decomposes naturally difficult. Organic content in the water to form potentially carcinogenic compounds peat include: THM (trihalomethane) in the process of disinfection with chlorine. Humic acid having a molecular weight 2000-100.000 daltons, have the potential to form organochlorines such as THM and HAA (haloacetic acids) is relatively higher than non humus compounds. Humic acid is formed from the decomposition of organic material by aerobic organisms. This acid has a molecular weight of 10,000 to $100,000 \mathrm{~g} / \mathrm{mol}$ [27]. Peat is accumulation vegetation that has died and then broken down by anaerobic and aerobic bacteria into components that are more stable. In addition to organic matter that forms peat are also inorganic substances in small quantities. In the environment of deposition of peat more than $90 \%$ under water-saturated conditions [28]

\section{REFERENCE}

[1] Y. Sulistiyanto, H. Vasandar, J. Jauhainen, J. O. Riely, and S. H. Limin, Mineral Nutrien Content of Water at Different Depths in Peatland In Central Kalimantan, 2007.

[2] R. H. Susanto, "The development wetlands multydispliner Indonesian regional. The paper to present to socialitiation of road map agriculture programe Indonesia," University of Helsinky, 2011.

[3] F. R. Spellman, Handbook of Water and Wastewater Treatment Plant Operations, Second Edition, by CRC Press - 872 Pages, 2008.

[4] Yusnimar, "Treatment of peat water by bentonite," Journal Sains dan Teknologi Fakultas Teknik, University of Riau, vol. 9, no. 2, pp. 77-81, 2010 .

[5] N. M. D. I. Lestari, "Effctivities to use bentonite and carbon active to removal ion $\mathrm{Fe}$ in peat water," FKIP Jambi University, 2003.

[6] M. Naswir, S. A. Marsi, and Salni, "The regional of water quality distribution of peat swamp lowland Jambi," International workshop on sustainable management lowland, 2012.

[7] E. R. I. D. W. Hadi, "The Study of Peat Water for drink water with Proces Upflow Anaerobik Filter (UAF) dan Slow Sand Filter (SSF) combination," Teknik Lingkungan FTSP-ITS Surabaya, 2008.

[8] S. Wardiati, "The adsortion to metal contaminant of $\mathrm{Cu}$ and $\mathrm{Ni}$ din the water by bentonite," Journal of Material Science Sains, vol. 10, no. 3, pp. $278-283,2007$.

[9] M. Naswir and H. Aima, "Study of Peat Moss water for consume water with CCBN-RO Technology," in Proc. Seminar International to UNSOED Jawa Tengah, 2008.

[10] A. G. Perez, A. M. Urtiaga, R. Ibanez, and I. Ortiz, "State of the art and riview on the tretment technologies of water reverse osmosis concentarates," Journal water research, vol. 46, pp. 267-283, 2012.

[11] Iswono. Effectivites Poly Aluminium Chloride for Colour peat water in Siantan Hulu Pontiakan city, Diponegoro University, 2001.

[12] D. F. D. Notodarmojo, "Removal colour and organic matter with Two Stage Coagulation," Journal Teknik Lingkungan ITB, vol. 13, no. 1, pp.17-26, 2007.

[13] M. Rozic, S. C. Scefanovic, S. kurajica, V. Vancina, and Hodzic, "Amoniacal Nitrogen Removal from water by treatment with Clays and Zeolite,” Journal Elsevier, Wat. Res., vol. 34, pp. 3675-3681, 1998.

[14] M. Rozic, S. C. Scefanovic, S. kurajica, V. Vancina, and Hodzic, "Amoniacal Nitrogen Removal from water by treatment with Clays and Zeolite," Journal Elsevier,Wat. Res., vol. 34. pp. 3675-3681, 1998.

[15] T. S. Soedjoko, "The Research to use Bentonite in Indonesian," Buletin PPTM, vol. 9, no. 2, pp. 15-24, 1987. 
[16] Zulfikar, Z. G. Iwan, and A. F. Yusuf, The continius study of Minerals in the around Tabir district of Jambi, Subdit Minies Instantion of Jambi, 2006.

[17] S. R. Wijaya and J. D. S. Rohman, "Modifikasi Bentonit (Clay) Menjadi Organoclay dengan Penambahan Surfaktan," Journ. Nano sains \& Nanoteknologi, BPPT, pp. 48-51, 2008.

[18] A. Fisli and H. Haeruddin, "Preparation and Characterization of Manganese Oxide Catalysts by Supporting Pillar Alumina Bentonite for Gas CO Oxidation," in Proceedings of the Scientific Meeting of Science and Technology, pp 257-264, 2002.

[19] S. Hong, C. Wen, J. He, F. Gan, and Y. S. Ho, "Adsorption Thermodinamics of Methylene Bleu onto Bentonite," Journal of Hazardous materials, vol. 167, pp. 630-633, 2009.

[20] J. L. Gilson, Industrial Mineral and Rock, the American Institute of Mining, Metallurgical and Petroleum Engineers, New York. Third Edition, 1960.

[21] V. KWK. (2005). Traditional Bentonet, Gusmer Interprosis, Industry. [Online]. Available: http://wiki.csinet.org.

[22] S. M. Bradley, K. R. A. Yamdagri, and R. C. A. Fyte, Expanded Clays and Other Microporous Materials, Syntesis of Microporous Materails, vol. 2, Vans Nonstrand Reihold, New York, 1992.

[23] M. N. A. Dahlan, H. A. N. E. Din, and A. A. A. Qahtani, "Stimulation of Sandstone Reservoirs Using Hydrofluoric- Based Acids," Journal of Technholgy Winter, pp. 31-39, 1998.

[24] R. E. Grim and Given, Bentonites, New York: Elsevier, vol. 256, 1978.

[25] S. J. Leefond, "Industrial Minerals and Rocks. American Institute for Mining," Metallurgical and Petroleum Engineers, 5th, edetion. New York, pp. 995-1025, 1983.

[26] Bentonite Clay waterproofing. [Online]. Available: http://wiki.c.sinct.org/

[27] A. I. Zouboulis., X. L. Cha, and I. A. D. Katsoyiannis, "The Application of Biofloculant for The Removal of Humic Acid rom
Stabilized Landfill Leachate," Enviromental Management Jornal, vol. 70, pp. 35-41, 2004.

[28] Sukandarrumidi, The Excavation og Materials Industry, Gajah Mada of University, Press, 1999.

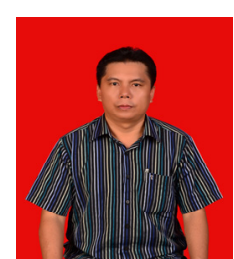

Drs. Muhammad Naswir was born in the village of West Sikaladi Sumetera Island Indonesia, on May 3, 1966. is a child of the husband keduan Pure Mother and father Mansur. Education Elementary School (SD) State Sikaladi graduated in 1972, went to Junior High School and graduated in 1982 Sikaladi. 1982 to 1985 to continue their education in high schools Batusangkar. Bachelor of Education in Guidance and Counseling in the travel Jambi University Chemistry Education Program and graduated in 1990. Pursue education Master Program (S2) at the Department of Chemistry Anaalitik 1998 and completed in 2001 at the University of Padjadjaran Bandung. And now in 2013 is currently completing Doctoral Program (S3) at Sriwijaya University Graduate Environmental Sciences. He worked as a lecturer in Chemistry University of Jambi, since 1991 till now. from year 2002 to year 2010 is trusted by Edinburgh University rector became chairman three Diploma courses Diploma Industrial Chemistry and Chemical Analysis at the University of Jambi, author, consultant environmental document. Drs. M. Naswir, M.Si the year 2007-2010 to help local governments in the field of expert the studies and the Office of Research and Development Jambi Provincial. Then he also active as a member of the Regional Research Council in 2007-2009 period. In 2008 received an award from the Governor of Jambi in the right order to create technology Wastewater into clean water Peat Society. The focus of the study is to examine the issue of minerals especially Bentonite started in 2004 until now, continue to perform community service in particular about the water supply. 